\title{
Occurrence of tayras (Eira barbara Linnaeus, 1758) with anomalous coloration in Cerrado remnants in the state of São Paulo, Brazil
}

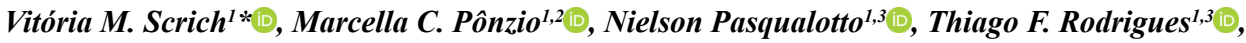 \\ Roberta M. Paolino ${ }^{1,3}$ \& \& Adriano G. Chiarello ${ }^{1}(\mathbb{D}$ \\ ${ }^{1}$ Universidade de São Paulo, Faculdade de Filosofia, Ciências e Letras de Ribeirão Preto, Departamento de \\ Biologia, Av. Bandeirantes, 3900, Monte Alegre, 14040-901, Ribeirão Preto, SP, Brasil \\ ${ }^{2}$ Universidade de São Paulo, Faculdade de Filosofia Ciências e Letras de Ribeirão Preto, Programa \\ de Pós-Graduação em Biologia Comparada, Av. Bandeirantes, 3900, Monte Alegre, 14040-901, \\ Ribeirão Preto, SP, Brasil \\ ${ }^{3}$ Universidade de São Paulo, Escola Superior de Agricultura “Luiz de Queiroz”, Programa de Pós Graduação \\ em Ecologia Aplicada, Av. Pádua Dias, 11, Caixa Postal 09, 13418-900, Piracicaba, SP, Brasil \\ *Corresponding author: Vitória M. Scrich, e-mail: vitoria.scrich@usp.br \\ SCRICH, V.M., PÔNZIO, M.C., PASQUALOTTO, N., RODRIGUES, T.F., PAOLINO, R.M., CHIARELLO, \\ A.G. Occurrence of tayras (Eira barbara Linnaeus, 1758) with anomalous coloration in Cerrado remnants \\ in the state of São Paulo, Brazil. Biota Neotropica. 19(3): e20180680. http://dx.doi.org/10.1590/1676-0611- \\ BN-2018-0680
}

\begin{abstract}
Coloration anomalies are mainly genetically-based disorders in which body pigmentation is either reduced (hypopigmentation) or produced in excess (melanism), in parts or the totality of the body. Cases of hypopigmentation have been documented in many neotropical mammals, including the tayra (Eira barbara Linnaeus, 1758). We expand the account of anomalous coloration occurrence presenting new registers of hypopigmented tayras in Brazil. Data was collected during a mammal survey carried out in three agricultural landscapes within the Cerrado domain in the northeast of the state of São Paulo. We obtained two kinds of records of hypopigmented tayras, one from direct sighting and the other from a camera-trap. We discuss the likely implications of this conspicuous coloration to tayras and highlight some possibilities of study.
\end{abstract}

Keywords: Anthropogenic matrix, hypopigmentation, leucism, mustelid, savannah, sugarcane.

\section{Ocorrência de iraras (Eira barbara Linnaeus, 1758) com coloração anômala em remanescentes de Cerrado no estado de São Paulo, Brasil}

\footnotetext{
Resumo: Colorações anômalas são desordens geralmente de origem genética, em que a pigmentação do corpo é reduzida (hipopigmentação) ou excessiva (melanismo), em partes ou totalmente. Casos de hipopigmentação já foram documentados em muitos mamíferos neotropicais, incluindo a irara (Eira barbara Linnaeus, 1758). Nós expandimos os relatos de ocorrência de colorações anômalas apresentando novos registros de iraras hipopigmentadas no Brasil. Dados foram coletados durante um levantamento de mamíferos em três paisagens agrícolas no domínio do Cerrado no nordeste do estado de São Paulo. Obtivemos dois tipos de registros de iraras hipopigmentadas, sendo um por avistamento e outro por armadilhas fotográficas. Nós discutimos possíveis implicações ecológicas dessa coloração em iraras e sugerimos novas possibilidades de estudos.

Palavras-chave: Cana-de-açúcar, hipopigmentação, leucismo, mustelideo, matriz antrópica, savana.
} 


\section{Introduction}

Animal coloration is widely involved in life processes such as concealment, communication, physiological regulation and sexual selection (Caro 2005). Presence and distribution of pigmentation in animals' skin, hair and eyes define different colour phenotypes (Fertl \& Rosel, 2002, Hofreiter \& Schöneberg 2010). The physical environment is an important selective force driving coloration patterns in mammals, resulting in a gradual variation in colour across populations (Ortolani 1999). Moreover, variation is also attributed to colour anomalies that occur when integumentary pigments are present in excess or deficient in parts or in totality of the body, being described as melanism, piebaldism, hypomelanism, leucism and albinism (Prota 1980, Fertl \& Rosel 2002, Lucati \& Lopez-Baucells 2016).

Specifically, leucism is a condition in which body pigmentation is fully absent, but differently from albinism, the eyes of leucistic animals retain normal coloration (Lucati \& Lopez-Baucells 2016). The subject is rather controversial, but most authors sustain that leucism is characterised by total or partial absence of pigmentation in the whole body except for the eyes and body extremities, which remain darkly pigmented (Fertl and Rosel, 2002; Miller, 2005; Acevedo and Aguayo, 2008). Leucism is commonly confounded with other hypopigmentary disorders, such as piebaldism and hypomelanism (Lucati \& LopezBaucells 2016). Piebaldism is a type of localised hypopigmentation, due to an absence of melanocytes in the affected skin and hair follicles or feathers. Piebald animals have normally coloured eye and a patchy distribution of spots on the body where both fur and skin are totally white (Lucati \& Lopez-Baucells 2016). Hypomelanism is another type of chromatic disorder that turns individuals yellowish due to an insufficiently pigmented skin (Lucati \& Lopez-Baucells 2016). In general, anomalous coloration are attributed to genetic hereditary causes (Bensch et al. 2000), involving the lack of production of tyrosinase, the enzyme involved in melanin biosynthesis (Sanchez-Ferrer et al. 1995), or a deficiency in the melanin transfer process, despite normal pigment production (Lucati \& Lopez-Baucells 2016). Despite strong selection pressures against hypopigmented animals, these anomalous colours have been recorded in many mammalian species (Fertl \& Rosel 2002, Abreu et al. 2013).

Coloration anomalies have been identified in terrestrial carnivore species such as the tayra (Eira barbara Linnaeus, 1758; Sobroza et al. 2016), the white-nosed coati (Nasua narica Linnaeus, 1766; Silva-Caballero et al. 2014) and the neotropical otter (Lontra longicaudis Olfers, 1818; Arriaga-Flores et al. 2016). The tayra is one of the most common medium sized carnivores in Neotropical forests (Emmons \& Feer 1997), being broadly distributed from central Mexico to northern Argentina (Presley 2000). Throughout its distribution, tayras with anomalous coloration have been identified in Guyana (Presley 2000), Bolivia (Tarifa et al. 2001) and Brazil (Trolle 2003, Reis et al. 2005, Tortato \& Althoff 2007, Sobroza et al. 2016, Aximoff \& Rosa 2016, Talamoni et al. 2017). The subspecies that occurs in most of Brazil, Eira barbara barbara, presents a dark brown body coat with a grey head and a whitish spot at the base of the neck extending to the chest (Presley 2000). To date, there are six reports evidencing anomalous coloration in tayras around the country. Two occurrences were described from Central Amazon, in the sub-basin of the Rio Negro (Trolle 2003) and from the "Cabo Frio" site of the Biological Dynamics of Forest Fragments Project (BDFFP) (Sobroza et al. 2016). In the south part of Brazil, whitish tayras were spotted on a farm in the state of Paraná, where native pastures are predominant (Reis et al. 2005), and in the state of Santa Catarina (Tortato \& Althoff 2007), within a transition area between mixed and dense Ombrophylous Forests. More recently, in the southeast region of Brazil, one record of an albino tayra was made in the Atlantic Forest of the Itatiaia National Park, Rio de Janeiro state (Aximoff \& Rosa 2016), and some records of leucistic tayras were made at the Private Reserve of Natural Heritage Santuário do Caraça, in Minas Gerais state, a transition zone between Cerrado (i.e. brazilian savanna) and Atlantic Forest (Talamoni et al. 2017). In this report, we present new records of anomalous coloration in tayras for the southern limits of the Brazilian Cerrado and the first record for the state of São Paulo.

\section{Materials and Methods}

The data presented here was collected during a project evaluating the effects of environmental variables and anthropogenic disturbance on occupancy of mammal species in southeast Brazil (Paolino et al. 2016, Rodrigues et al. 2017). The study was carried out in three agricultural landscapes within the Cerrado domain in São Paulo state (Figure 1). The region is also a transition zone between Cerrado and Atlantic Forest, characterized often by remnants of Cerrado physiognomies, mostly "Cerradão" (sclerophyllous woodland, Toppa 2004). The remnants are surrounded by a heterogeneous matrix made up of Eucalyptus and sugarcane plantations, other agricultural crops and urban areas (Rodrigues et al. 2017). Each of the three study landscapes differed in land cover type composition. Landscape A included two protected areas called Jataí Ecological Station (JES) and Luiz Antônio Experimental Station (LAES), adjacent to each other; landscape B included Legal Reserves and Areas of Permanent Protection (Soares-Filho et al. 2014) of a private area owned by International Paper called Cara Preta Farm (CPF); and landscape $\mathrm{C}$ included a protected area called Cajuru State Forest (CSF), Areas of Permanent Protection and a Legal Reserve of another private farm from International Paper called Dois Córregos Farm (DCF). We also collected data (see below) in a buffer zone up to $2.6 \mathrm{~km}$ from the perimeters of the protected areas, Legal Reserves and Areas of Permanent Protection mentioned above (Figure 1).

A regular grid of 200 ha cells was overlaid on the study landscapes and a single camera-trap (Reconyx ${ }^{\circledR}$, model HC 500) was placed in the centre of each cell. From April to September 2013-2014, 208 sites were sampled with all camera-traps spaced approximately $1.4 \mathrm{~km}$ apart on each landscape. Camera-traps were systematically placed inside JES-LAES $(\mathrm{n}=52), \mathrm{CPF}(\mathrm{n}=25)$ and CSF-DCF $(\mathrm{n}=24)$ and a similar number was randomly placed in the buffer zone around each one. We programmed the cameras to monitor 24 hour/day and each of them operated continuously for about 30 days, totalling a sampling effort of 6,380.92 camera-trap days. We fixed the camera-traps on tree trunks 40-60 $\mathrm{cm}$ above the ground. Additionally, we actively searched for signs (footprints, scats, etc.) or sightings in the surroundings of each camera-trap during their installation and removal.

\section{Results and Discussion}

Over the whole study period, we detected tayras in 17 out of 208 sampling sites $(8.17 \%)$. We obtained two records of yellow-whitish tayras, one from an animal directly sighted by us and the other from 

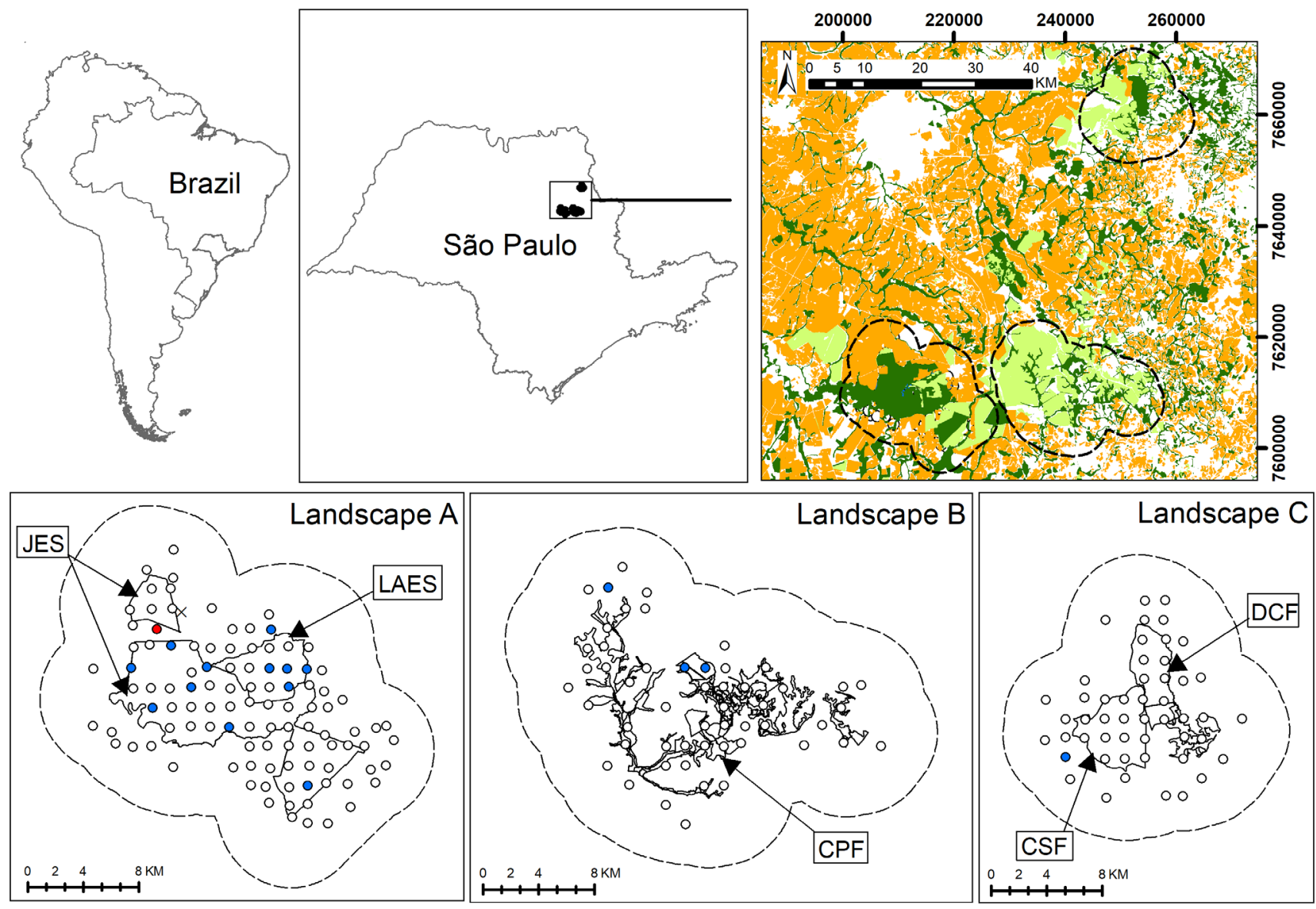

Cartographic base: IBAMA 2008; CANASAT 2013; Ribeiro, M.C. - Catrographic projection: UTM / DATUM: SIRGAS2000 / Zone: 23 S

Landscape A, B and C: 1:596,000

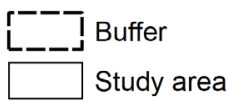

- Sampling units
Native Vegetation

Managed Forest

Sugar cane

\section{- Non-Leucistic Tayra Record (Camera-trapping) \\ $X \quad$ Leucistic Tayra Record (Visual sighting) \\ - Leucistic Tayra Record (Camera-trapping)}

Figure 1. Details of the study areas. Landscape A: Jataí Ecological Station (JES) and Luis Antônio Experimental Station (LAES); Landscape B: Cara Preta Farm (CPF); Landscape C: Cajuru State Forest (CSF) and Dois Córregos Farm (DCF). Each sampling unit is represented by uncoloured dots; blue dots represent tayra registers by camera trap and the red dot shows the location where leucistic tayras were detected by camera trap; the "x" represents the location where the leucistic tayra was recorded by visual sighting.

a single camera-trap ( $\mathrm{n}=15$ photographs). The sighted individual was crossing a paved road that separates a sugarcane field from native vegetation $\left(21^{\circ} 32^{\prime} 27.5^{\prime \prime} \mathrm{S}, 47^{\circ} 48^{\prime} 09.3^{\prime \prime} \mathrm{W}\right)$ at 15:30 on August 2013. The record from the camera-trap shows two tayras moving along an unpaved road at 7:58 on May 2013 (Figure 2). This unpaved road is also located between native forest and a sugarcane field ( $21^{\circ} 33^{\prime} 06.5^{\prime}$ ' $\left.\mathrm{S}, 47^{\circ} 49^{\prime} 12.0^{\prime \prime} \mathrm{W}\right)$.

The two records are $2167 \mathrm{~m}$ apart and both are in the buffer zone of Jataí Ecological Station (landscape A), the largest Cerrado remnant of São Paulo state. The 200 ha buffer around the camera station where tayras with anomalous coloration were photographed is predominantly covered by closed native vegetation ("Cerradão"). It was not possible to discriminate the sex of the individuals with certainty, but the difference in body size between them suggests it could be either a female with a juvenile offspring or an adult couple, since male tayras are in general 30\% larger than females (Kaufmann \& Kaufmann 1965).

According to the definitions of anomalous coloration in mammals given by some authors (e.g. Fertl and Rosel, 2002; Miller, 2005; Acevedo and Aguayo, 2008) and considering the characteristics shown by the reported individuals (apparent lack of colour throughout the body and maintenance of dark pigmentation in the eyes and in the body extremities such as the nose), our records may represent leucistic tayras. However, considering the most recent definition of leucism, given by Lucati \& Lopez-Baucells (2016), the entire body of a leucistic animal would have a white or whitish colour. Being mindful of the terminology misuse of anomalous coloration in the scientific literature, we refrain to designate our records as cases of leucism because we cannot precisely differentiate leucism from another hypopigmentary disorder like hypomelanism, given the nature of our data. For example, we are not sure that the tayras that we recorded present darker extremities as these might have resulted not from pelage coloration but from dirt or from shadows in the camera-trap photos. Nevertheless, tayras with normal coloration have browner body extremities than the observable in these two individuals, as shown in Figure 3. Anomalous colour phenotypes have been already identified in tayras across different landscapes and areas of occurrence, mainly in Brazil (Talamoni et al. 2017). Although hypopigmentation in 


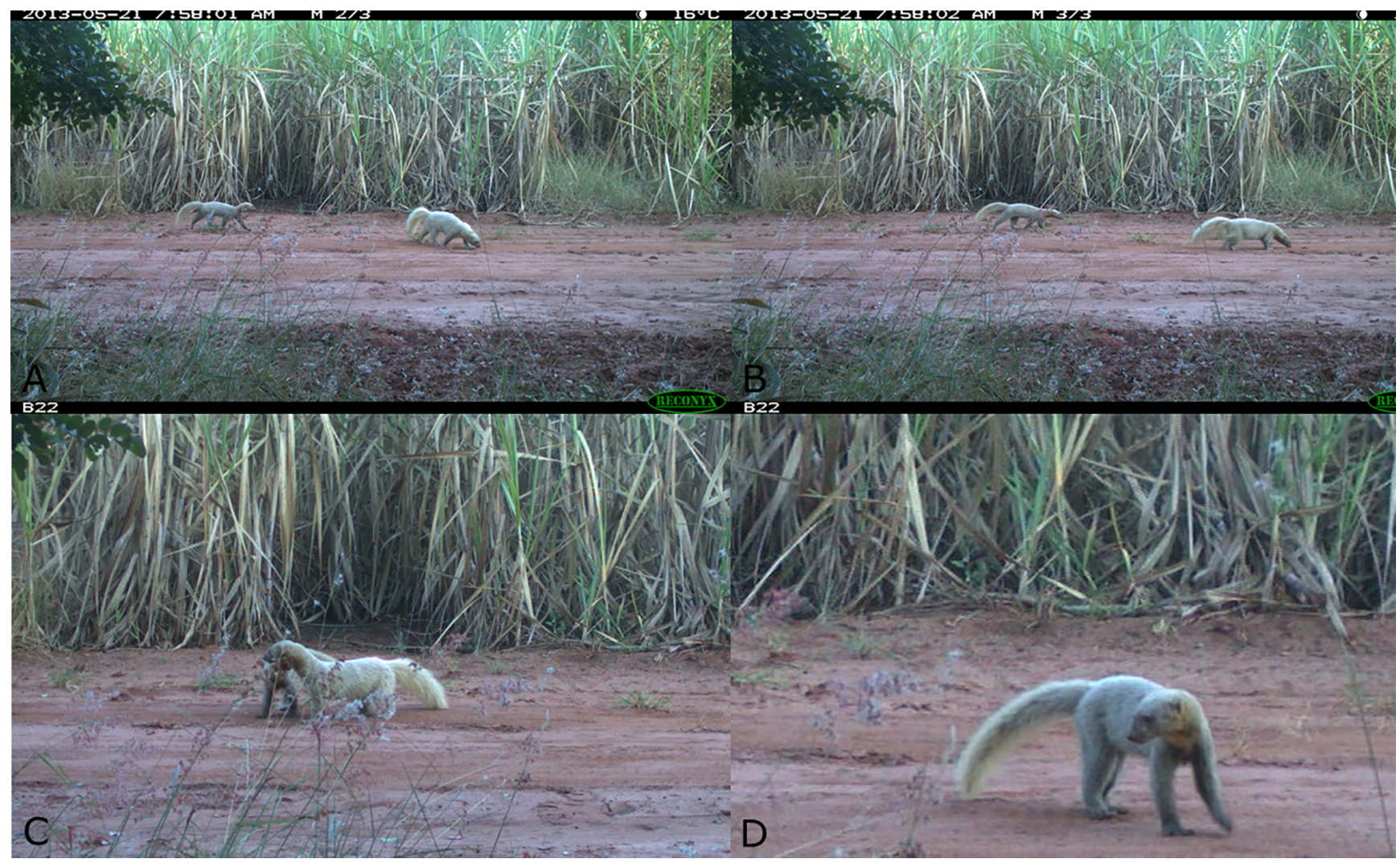

Figure 2. A, B and C. Pair of leucistic greyheaded tayras registered in landscape A (buffer zone of Jataí Ecological Station), in the state of São Paulo, Brazil; D. Highlight in one of the two individuals registered by camera trap.

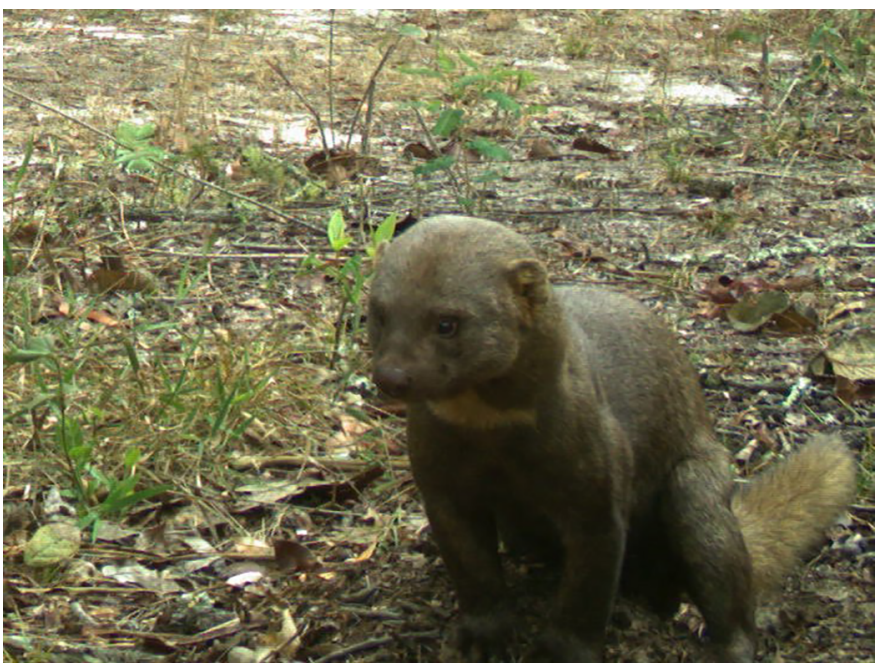

Figure 3. Tayra presenting normal coloration, registered by camera-trap.

tayras have been detected in the Amazon, the Atlantic Forest and in a transitional area between Cerrado and Ombrophyllous Forests (Presley 2000, Trolle 2003, Reis et al. 2005, Tortato \& Althoff 2007, Sobroza et al. 2016, Aximoff \& Rosa 2016), our records are the first ones for the Cerrado region in the state of São Paulo, Brazil.

The occurrence of anomalous coloration in tayras recorded twice at landscape A (JES/LAES and surroundings) represent $13.3 \%$ of the records we obtained from this species in this landscape. This proportion of anomalous coloration over the low number of tayras recorded during the two-year study could be indicative of a small and isolated population that resulted from Cerrado deforestation and fragmentation (Seoane et al. 2010). The Jataí Ecological Station is an example of such fragment, being a Cerrado remnant (mostly "Cerradão") surrounded by an anthropogenic matrix where sugarcane plantations predominate (Toppa 2004, Rodrigues et al. 2017). Nevertheless, apart from genetic assessment, we need further data on local population size and on dispersal potential of tayras through anthropogenic matrices to back this.

Studies of animal coat coloration can provide useful information on their ecology, however, reports of hypopigmentation in tayras lack the ecological implications of this phenotype (Talamoni et al. 2017). For instance, the possibility that tayras with partial or total lack of pigmentation are more susceptible to predation, due to its outstanding coloration at different environments, has never been tested nor assessed. Yet, this condition might turn hypopigmented tayras more vulnerable to larger, visually oriented carnivores such as cougars (Puma concolor Linnaeus, 1771) and ocelots (Leopardus pardalis Linnaeus, 1758), both of which are known to occur in our study area (Paolino et al. 2016). It is indeed possible to design and set up camera-trap appropriately in order to overcome the key limitation of individual identification, a necessary condition to estimate survival probabilities of classic population models. Villafañe-Trujillo \& López-González (2018), for example, were able to identify individual tayras thorough pelage pattern of the head and chest. Estimating parameters such as survival rate could also help to investigate the possibility that individuals with anomalous coloration would have adaptive advantages (Talamoni et al. 2017). Conspicuous colour patterns in vertebrates are involved in a 
variety of intra and interspecific communicative interaction (Rowland 1979; Butcher \& Rohwer 1989). Such abnormal coloration may aid in the recognition of species (Smith 1967), individuals (Miller \& Eden 1975) and sexes (Noble 1936); may be used during territorial defence and aggression (Noble 1934; Tinbergen 1953); or to express courtship and mate preferences (Endler 1987, Houde \& Endler 1990). According to Presley (2000), deficits in pigmentation production are more common in tayras than in other mustelids, therefore, reports on tayras' anomalous coloration across various landscapes present opportunities to investigate possible ecological adaptations in specific habitats. Given the nature of our records we cannot accurately infer about the population and ecological consequences of the anomalous colorations for the population of tayras in the Cerrado of São Paulo. However, we hope our records encourage further research on the basic causes of this phenomenon and its putative relationship with the environment.

\section{Acknowledgments}

We thank São Paulo Research Foundation (FAPESP 2011/22449-4) for financial support and Coordenação de Aperfeiçoamento de Pessoal de Nível Superior (CAPES) for granting a scholarship. We are also grateful to Instituto Florestal, Fundação Florestal and International Paper (Brazil) for providing necessary support to make this study possible. AGC has a fellowship from the Brazilian Science Council (303101/2017-2).

\section{Author Contributions}

Vitória M. Scrich: Contribution to manuscript preparation; Contribution to data analysis and interpretation.

Marcella C. Pônzio: Contribution to manuscript preparation; Contribution to data analysis and interpretation.

Nielson Pasqualotto: Contribution to data collection; Contribution to critical revision, adding intelectual content.

Thiago F. Rodrigues: Contribution to data collection; Contribution to critical revision, adding intelectual content.

Roberta M. Paolino: Contribution to data collection; Contribution to critical revision, adding intelectual content.

Adriano G. Chiarello: Substantial contribution in the concept and design of the study; Contribution to data analysis and interpretation; Contribution to critical revision, adding intelectual content.

\section{Conflict of Interest}

The authors declare that they have no conflict of interest related to the publication of this manuscript.

\section{References}

ABREU, M. S. L., MACHADO, R., BARBIERI, F., FREITAS, N. S. \& OLIVEIRA, L. R. 2013. Anomalous colour in Neotropical mammals: a review with new records for Didelphis sp. (Didelphidae, Didelphimorphia) and Arctocephalus australis (Otariidae, Carnivora). Brazilian Journal of Biology. 73:185-194.

ACEVEDO, J. \& AGUAYO, M. 2008. Leucistic South American sea lion in Chile, with a review of anomalously color in ottarids. Revista de Biología Marina y Oceanografía. 43:413-417.
ARRIAGA-FLORES, J.C., RODRÍGUEZ-RUÍZ, E. R., GALLO-REYNOSO, J.P. \& CASTRO-ARELLANO, I. 2016. Leucism in Neotropical otters (Lontra longicaudis annectens) from Mexico. Southwestern Naturalist. 61:63-68.

AXIMOFF, I. A. \& DA ROCHA, C. A. 2016. First records of albinism in greyheaded tayra (Carnivora, Mustelidae) and occurrence in high-altitude grassland in Brazil. Oecologia Australis. 20:4.

BENSCH, S., HANSSON, B., HASSELQUIST, D. \& NIELSEN, B. 2000. Partial albinism in a semi-isolated population of Great Reed Warblers. Hereditas. 133:167-170.

BUTCHER, G. S. \& ROHWER, S. 1989. The evolution of conspicuous and distinctive coloration for communication in birds. Current Ornithology. 6: 51-108.

CARO, T. 2005. The adaptive significance of coloration in mammals. BioScience. 55:125-136.

EMMONS, L. H. \& FEER, F. 1997. Neotropical rainforest mammals: a field guide. The University of Chicago Press. 2:396.

ENDLER, J. A. 1987. Predation, light intensity and courtship behaviour in Poecilia reticulata (Pisces: Poeciliidae). Animal Behaviour. 35:1376-1385.

FERTL, D. \& ROSEL, P. 2002. Albinism. Encyclopaedia of Marine Mammals Academic Press, San Diego. 1:16-18.

HOUDE, A. E. \& ENDLER, J. A. 1990. Correlated evolution of female mating preferences and male color patterns in the guppy Poecilia reticulata. Science. 248:1405-1408.

KAUFMANN, J. H. \& KAUFMANN, A. 1965. Observations of the behavior of Tayras and grisons. Zeitschrift für Säugetierkunde. 30:146-155.

LUCATI, F. \& LOPEZ-BAUCELLS, A. 2016. Chromatic disorders in bats: a review of pigmentation anomalies and the misuse of terms to describe them. Mammal Review. 47.

MILLER, D. E., \& EDEN, J. T. 1975. Individual chick recognition and family integrity in ring-billed gull. Behaviour. 52:124-144.

MILLER, J. D. 2005. All about albinism. Missouri Conservationist. 66:5-7.

NOBLE, G. K. 1934. Experimenting with the courtship of lizards. Natural History. 34: 1-15.

NOBLE G. K. 1936. Courtship and sexual selection of the flicker (Colaptes aurates luteus). Auk. 52: 269-282.

ORTOLANI, A. 1999. Spots, stripes, tail tips and dark eyes: predicting the function of carnivore colour patterns using the comparative method. Biological Journal of the Linnean Society. 67:433-476.

PAOLINO, R. M., VERSIANI, N. F., PASQUALOTTO, N., RODRIGUES, T. F., KREPSCHI, V. G. \& CHIARELLO, A. G. 2016. Buffer zone use by mammals in a Cerrado protected area. Biota Neotropica. 16(2): e20140117. http://dx.doi.org/10.1590/1676-0611-BN-2014-0117 (last access on 10/10/2018).

PRESLEY, S. J. 2000. Eira barbara. Mammalian species. 636:1-6.

PROTA, G. 1980. Recent advances in the chemistry melanogenesis in mammals. Journal of Investigative Dermatology. 75:122-127.

REIS, N. R., PERACCHI, A. L., FANDIÑO-MARINO, H. \& ROCHA, V. J. 2005. Mamíferos da Fazenda Monte Alegre - Paraná. 1st ed. Londrina, PR: Eduel. 1:224

RODRIGUES, T. F., KAYS, R., PARSONS, A., VERSIANI, N. F., PAOLINO, R. M., PASQUALOTTO, N., KREPSCHI, V. G. \& CHIARELLO, A. G. 2017. Managed forest as habitat for gray brocket deer (Mazama gouazoubira) in agricultural landscapes of southeastern Brazil. Journal of Mammalogy. 98:1301-1309.

ROWLAND, W. J. 1979. The use of colour in intraspecific communication. Burtt EH Jr, ed. The Behavioural Significance of Color. New York: Garland STPM Press. 7:379-421.

SANCHEZ-FERRER, A., RODRÍGUES-LÓPEZ, J. N., GARCÍA-CÁNOVAS, F. \& GÁRCIA-CARMONA, F. 1995. Tyrosinase: a comprehensive review of its mechanism. Biochimica et Biophysica Acta. 1247:1-11.

SMITH, D. G. 1967. Visual isolation in gulls. Scientific American. 217: 94-102.

SEOANE, C. E. S., DIAZ, V. S., SANTOS, T. L. \& FROUFE, L. C. M. 2010. Corredores ecológicos como ferramenta para a desfragmentação de florestas tropicais. Pesquisa Florestal Brasileira. 30: 207. 
Scrich, V.M. et al.

SILVA-CABALLERO, A., MONTIEL-REYES, F., SÁNCHEZ-GARIBAY, E. \& ORTEGA, J. 2014. Leucismo en el coatí de nariz blanca Nasua narica (Mammalia: Carnivora), en Quintana Roo, México. Therya. 5:839-843.

SOARES-FILHO, B. ET AL. 2014. Cracking Brazil's Forest Code. Science. 344: 363-364.

SOBROZA, T. V., GONÇALVES, A.L. \& DOS SANTOS, L. S. 2016. Predation attempt and abnormal coat coloration of the tayra (Eira barbara) in the Brazilian Central Amazon. Studies on neotropical fauna and environment. 51: 231-234.

TALAMONI, S., VIANA, P. I. M., COSTA, C. G., PALÚ, L., OLIVEIRA, R. B. \& PESSÔA, L. M. 2017. Occurrence of leucism in Eira barbara (Carnivora, Mustelidae) in Brazil. Biota Neotropica. 17(3): e20170328. http://dx.doi. org/10.1590/1676-0611-bn-2017-0328 (last access on 10/10/2018).

TARIFA, T., ALIAGA, E. , RÍOS, B. \& HAGAMAN, D. 2001. Mamíferos del Parque Nacional Madidi. Hisbol, La Paz, Bolivia.

TINBERGEN, N. 1953. Social Behaviour in Animals. London: Chapman and Hall.
TOPPA, R. H. 2004. Estrutura e diversidade florística das diferentes fisionomias de Cerrado e suas correlações com o solo na Estação Ecológica do Jataí, Luiz Antônio, SP. Tese de Doutorado, Universidade Federal de São Carlos, São Carlos, SP.

TORTATO, R. F., \& ALTHOFF, S. L. 2007. Variações na coloração de iraras (Eira barbara Linnaeus, 1758, Carnivora, Mustelidae) da Reserva Biológica Estadual do Sassafrás, Santa Catarina, sul do Brasil. Biota Neotropica. 7(3). Available on http://www.redalyc.org/articulo.oa?id=199114292037 ISSN 1676-0611 (last access on 10/10/2018).

TROLLE, M. 2003. Mammal survey in the Rio Jauaperí region, Rio Negro Basin, the Amazon, Brazil. Mammalia. 67:75-83.

VILLAFAÑE-TRUJILLO, Á. J., LÓPEZ-GONZÁLEZ, C. A. \& KOLOWSKI, J. M. 2018. Throat patch variation in tayra (Eira barbara) and the potential for individual identification in the field. Diversity. 10:7.

Received: $18 / 10 / 2018$

Revised: $13 / 02 / 2019$

Accepted: 19/03/2019

Published online: 11/04/2019 